\title{
Accessibility patterns: Finland Case Study ${ }^{1}$
}

\author{
Ossi Kotavaara, Harri Antikainen, Jarmo Rusanen \\ Department of Geography, \\ University of Oulu \\ PenttiKaiterankatu 1, 90570 Oulu, Finland \\ ossi.kotavaara@oulu.fi,harri.antikainen@oulu.fi,jarmo.rusanen@oulu.fi
}

\begin{abstract}
The case study of Finland analyses accessibility in one of the most sparsely populated countries in Europe. The findings of this study are based on grid cell analyses which are free from administrative divisions. In the analysis of accessibility of the population and jobs, the presence of both urban densities and extreme scarcityis evident, and this polarisation is deepening due to the location choices of companies and the overall urbanisation process. However, the availability of services is relatively good, even in peripheral areas, which is characteristic of health care accessibility. The regional structure of Finland favours travelling by car, particularly in the areas outside of urban centres. Moreover, in peripheral areas the service level and availability of public transport is limited and in some cases public transport may not be available at all. Due to maturity of transport networks and low demand, accessibility in Finland would be difficult to improve by developing infrastructure. Even though TEN-T policies are actively exploited in Finland, the great majority of projects are focused on improving nodal transport infrastructure, and only a few transport links are improved.
\end{abstract}

Keywords: accessibility, transport infrastructure, accessibility pattern, TEN-T, GIS, raster approach, Finland.

\section{Case study introduction}

Finland is the eighth largest country in Europe in terms ofthe surfacearea and the most sparsely populated country in the European Union. Situated in the Fennoscandian region of northern Europe, Finland is bordered by Sweden, Norway and Russia, while Estonia lies to its south across the Gulf of Finland. Hence, in terms of transport, Finland is situated almost like an island with respect to the rest of the European Union (Figure 1). Seasonal, but particularly winter, conditions need to be taken into account in road and maritime transport and as well as in rail and air transport.

Around 5.4 million people live in Finland, with the majority concentrated in the southern part of the country. On a north-south axis, the country is about $1,300 \mathrm{~km}$ long, and about $500 \mathrm{~km}$ wide

1 This paper has been developed under the applied research project TRansport ACCessibility at regional/local scale and patterns in Europe led by Spiekermann \& Wegener Urban and Regional Research (S\&W) Germany. It has been financed by the ESPON 2013 Programme and its financial support is gratefully acknowledged. Texts, maps and conclusions stemming from research projects under the ESPON programme presented in this paper do not necessarily reflect the opinions of the ESPON Monitoring Committee. (C) ESPON, 2013. 
at the most. Half of the population lives in the $200 \mathrm{~km}$-wide zone along the south coast. In addition to the growing urban centres and their sprawling fringes, small rural population centres and deep peripheries are characteristic of the Finnish regional structure. Indeed, about $80 \%$ of the population occupies an area of just $6,000 \mathrm{~km}^{2}$, while the area of the entire country is $338,000 \mathrm{~km}^{2}$. The standard of living, education and product per capita are at a high level.

The transport system of Finland is distinguished from most other European countries mainly by the maturity of the network, broadly distributed demand, and challenging seasonal conditions. The travel distances are long, transport flows are thin, and congestion problems occur only in the biggest cities. The winter season and the presence of inland water bodies are the most important environmental conditions affecting the Finnish transport system. Presently, inland waters, characterised by a highly fragmented structure, act as natural obstacles to transport, except in South-Eastern Finland and particularly in the Lake Saimaa region, where lakes and streams can be used as waterways. Hills are characteristic of some regions and fells are the prevailing landform in the northernmost areas, where the country's highest altitude of 1,324 metres is to be found. Otherwise, the relatively smooth topography does not restrict transport to any significant extent. The climate shows characteristics of both maritime and continental climate without a dry season. The weather conditions may occasionally be severe in the winter season, which may seriously impede maritime transport and also affect road and rail transport.

In these circumstances, an efficient transport system serving the economy, production, everyday life and tourism, among others, is critical for Finland. The present transport policies strive to guarantee good quality of key transports. While the extensive peripheral road network is subject to gradual degeneration, maintenance and improvement of the main transport links is seen as essential to economic development of the regions. In practice, the emphasis is set to ensure the quality of internal connections, most essentially the main domestic routes and the transport systems of the biggest cities.

The Finland case study region covers continental Finland only. The region of the Aland Islands is excluded from the case study due to its autonomous status and distinctive conditions of accessibility. However, the coastal archipelago is included in the analysis in cases where islands have a road infrastructure and a road ferry link integrating it with the continental road network. 


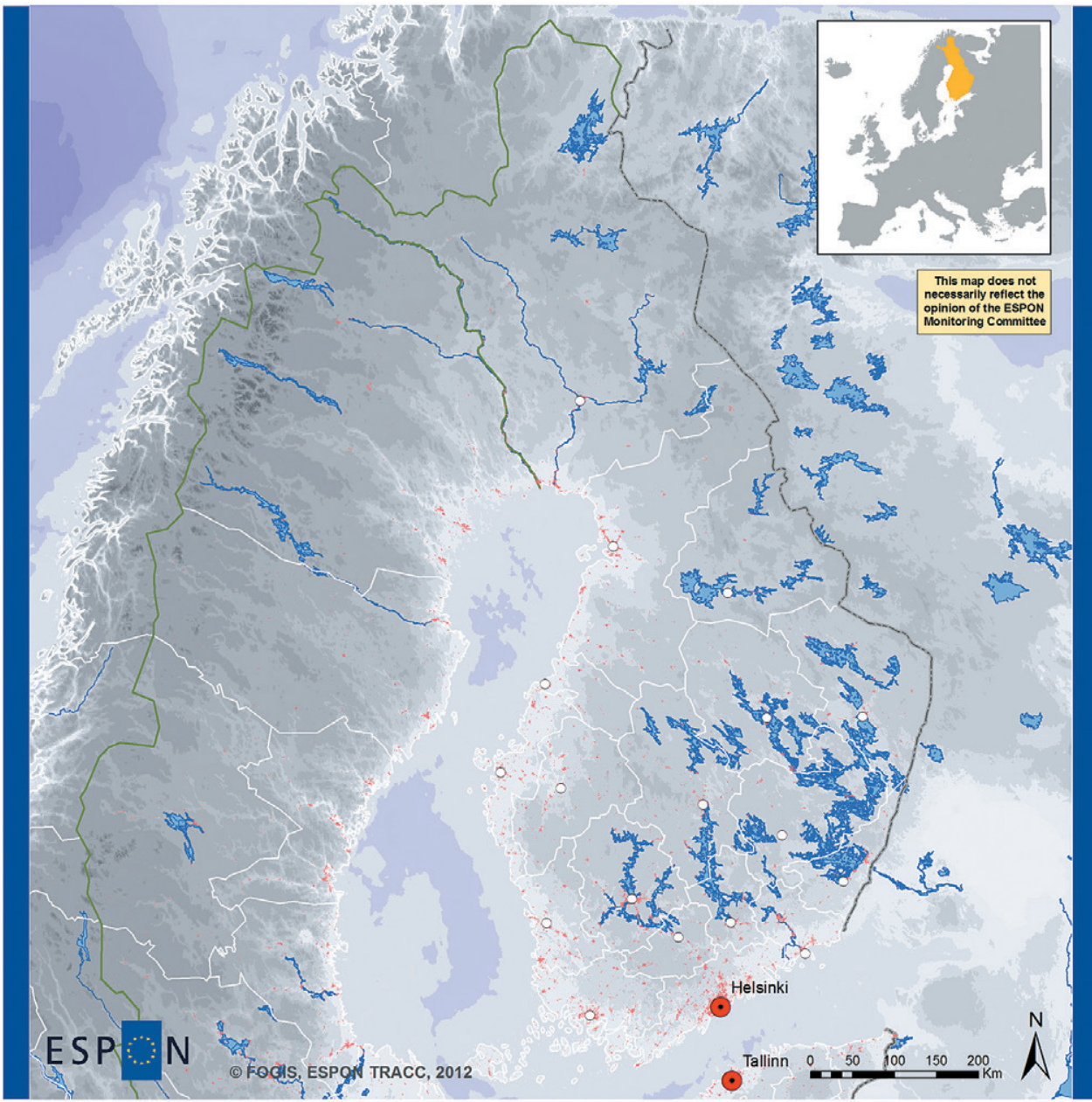

$\because \quad$ EUROPEAN UNION

Part-financed by the European Reglonal Development Fund

Data source: NOAA 2009; ESRI 2008; EEA 2006 Origin of data: ESPON Databank Project, 2010/2011 (c) EuroGeographics Association for administrative boundaries

\section{Finland Case Study Overview map}

- Capital city

- NUTS-3 capital

\section{Settlement area}

Figure 1. Finland case study region.

\section{Spatial structure}

Compared to the general trend in the Western world, Finland experienced relatively late urbanisation, which truly began in the 1960s in conjunction with increased motorisation and accessibility (Kotavaara et al. 2011a, 2011b). A total of $81.2 \%$ of the population live in urban areas and their 
immediate surroundings (Statistics Finland 2011). The Greater Helsinki area constitutes $25 \%$ of the country's population, including three cities with more than 200,000 inhabitants (Helsinki, Espoo and Vantaa). Other major cities in the case study region are Tampere (population of 210,000), Turku $(175,000)$, Oulu $(140,000)$, Jyväskylä $(130,000)$ and Lahti $(100,000)$. These are the only cities with a population of more than 100,000 .

The Finnish population is concentrated in the capital region and in the biggest cities with universities. In 2010, half of the 336 municipalities had fewer than 5,900 inhabitants. Even though the fertility rate is generally higher in rural areas, the death rate is higher than birth rate in 200 municipalities. The density of municipalities is high in the southern parts of the county, but in sparsely populated Easternand NorthernFinland distances between municipal centres may exceed 100 kilometres.

Economic activity and employees are even more concentrated in the cities than the population in relative terms. This is related to the fact that in the capital region in particular, there is a great deal of commuting from the suburbs to the city centre. The capital region, other main growth centres and county centres are the true drivers of the economy as a whole, whereas some peripheral areas have tourist attractions, industry, mining and primary production, which considerably affect the regional economy. A significant percentage of economic activityis concentrated in the Helsinki metropolitan area, as well as in regional centres with a university or other public or private research institutions. The northern parts of Finland are extremely sparsely populated with only small local centres, with the exception of Oulu, which is a relatively large and economically active population centre located in Northern Finland.

\section{Socio-economic situation}

Finland has evidently become a post-industrial economy, portrayed by service-emphasised employment $(72.9 \%)$. Industry, however, plays an important role $(14.7 \%)$ in comparison to construction (6.3\%) and primary production (3.7\%) (Statistics Finland 2012a).Hence, the regional structure of Finland has become polarised towards the development of urban cores competing strongly in the market economy and also towards the degeneration of peripheries facing continuous structural changes (Rusanen et al. 2003). Over the past decade, the unemployment rate has fluctuated at around $8 \%$ and in 2011 the figure was $7.8 \%$ (Statistics Finland 2012b).

The Uusimaaregion, and the Helsinki metropolitan area in particular, constitutes the major political, educational, financial, cultural and intellectual centre of Finland. Approximately $70 \%$ of the foreign companies operating in Finland have settled in the Helsinki region. The region accounts for about 38.7\% of the entire GDP of Finland (Statistics Finland 2012c). The northern and eastern areas of Finland are generally considered one of the least developed and most peripheral parts of Finland, where many socio-economic problems, such as unemployment, are apparent. Generally, the population of these regions is in decline, and the population there is becoming increasingly older. Possible exceptions to this can be found in the areas with expanding tourism or mining industry. Traditionally, the economy of Finland relied on heavy industry, and subsequently on strong ICT industry. However, at the moment, a remarkable structural change is taking place towards a more scattered economy.

\section{Transport aspects}

The Finnish transport system and transport policies are strongly related to activities ofthesociety, industry and business, and again to employment and regional development. The emphasis of the present policies is on developing emission efficiency and traffic safety, as well as supporting investments. Transport accounts for over 7\% of GDP. The transport system and its development is fundedby 
the stateto the tune of EUR 1.5 billion, while municipalities allocate nearly as much funding. In addition to accessibility effects and direct funding, the construction of transport infrastructure also brings other economic benefits to the regions.

The long transport distances within and between population centres of Finland favour the use of private cars which, indeed, dominate the Finnish passenger transport. The bus and coach networks with reasonable departure densities are largely restricted to urban areas, as demand for public transport is low in peripheral areas. The Finnish railway network connects the regional centres well around the country, and the most important urban centres in Finland are served by fast intercity connections. However, the number of railway stations and of the connections provided between them has been reduced remarkably, and in the present situation railway connections are available for few places in the periphery. The extent of the railway network has remained almost unchanged since the early 20th century, the only upgrades involving the construction of shortcut links between some important population centres (the most recent of which being that between Helsinki and Lahti, completed in 2006).

Due to its position as the capital of Finland, Helsinki and its surrounding region is well connected to the rest of the country by roads, railways and air traffic. The public transport system of Helsinki, involving local train, metro and tram networks, is more extensive than of any other city in Finland. Airports cover the country's largest towns quite well and they play an especially important role in the far north. The main international airport of Finland is situated in the Helsinki region. The airport is located remotely from Central Europe, but serving as an important connection hub between Europe and East Asia. It is also the main hub for domestic traffic, handling $77 \%$ of air transport passengers in 2012. The Finnish regional centres are connected with various scheduled flights to Helsinki. Stemming from its distance from the capital city, there are a lot of scheduled flights between Oulu and Helsinki, and as a result the accessibility of the Oulu region by air transport is fairly good. In fact, the Oulu region has the second busiest airport in Finland, measured in passenger numbers. The airports in the northern parts of the region improve the domestic and charter-based international tourism accessibility in their surrounding areas.

In addition to the very busy maritime freight traffic, passenger ferries operate frequently to Sweden, Estonia and Germany. The present transport use of inland waterways is limited to the south-eastern parts of Finland. Domestic passenger traffic by sea is, however, almost non-existent.

\section{Accessibility patterns}

Daily accessibility of jobs was calculated by using the grid cell database maintained by Statistics Finland. For travel by car, travel time has been estimated according to speed limits as expressed in the road network database provided by the Finnish Transport Agency. Due to the relatively large geographic size of municipalities in Finland, grid cell based computations were applied to increase the accuracy of the analyses. However, in order to enhance the calculation of accessibility, the original $1 \times 1 \mathrm{~km}$ grid cells were aggregated into $2 \times 2 \mathrm{~km}$ cells. The results are comparable to analyses based on administrative units as far as regional patterns are concerned, but with the grid cell analysis, also sub-municipal patterns can be identified, and uninhabited areas can be excluded in the visualisation of the indicators.

For analysing the accessibility of the population, the regional accessibility potential index was applied (Biosca et al., 2013). The above transport network was used, along with the grid-based population aggregated into $2 \times 2 \mathrm{~km}$ cells. 
The travel time to regional centres was calculated using multimodal public transport travel chains including bus/coach and rail links, as well as walking. The bus network consists of bus stop data from 2012, and estimated bus travel speeds. The bus network data have been built upon road data by determining the sections of the network that include bus stops. For long-distance coach transport, speed was estimated to be $30 \mathrm{~km} / \mathrm{h}$ in urban areas, and $60 \mathrm{~km} / \mathrm{h}$ in other areas. For bus traffic in urban areas, the figures were $20 \mathrm{~km} / \mathrm{h}$ and $30 \mathrm{~km} / \mathrm{h}$, respectively. Railway connections are based on timetable information about travel times between stations. Bus stops and railway stations serve as access points to the public transport network, and the speed of reaching the network was assumed to be $6 \mathrm{~km} / \mathrm{h}$, representing typical walking speed. Access to and exit from the railway network was assigned a 5-minute time penalty.

Accessibility of specialised health care facilities, that is regional hospitals, was calculated as travel time via the road network by car. In order to analyse the accessibility of hospitals, locations of the university hospitals, central hospitals and regional hospitals in 2011 were originally obtained in the form of street addresses, and located by means of geocoding.

\section{Daily accessibility of jobs by car}

The Helsinki metropolitan region enjoysclear dominance in terms of job accessibility by car (Figure 2). This job agglomeration effect reaches far into the surrounding areas via radial motorway connections in all directions. The agglomeration of jobs in the Helsinki region is visible in the urban area class. The average of the region is almost 700,000 accessible jobs, while the values fall below 30,000 at the edge of the region. By grid cell analysis it can be visualised that jobs are easily accessible around the regional centres, whereas apparent peripheries exist in central, eastern and particularly in northern areas. Intermediate regions close to a city include areas of both good and poor accessibility of jobs, whereas remote and rural areas suffer from poor accessibility to jobs. Hence, it can be concluded that even though the regional centres cover the Finnish population well, there are significant differences in the hierarchy of the centres. Within urban regions, $80 \%$ of the population can reach over 650,000 jobs by car, but 100,000 jobs are within the reach of $\%$ of therural population, even though a relatively wide time zone of 60 minutes was used in the analysis. It needs to be recognised, though, that a relatively low number of accessible jobs may still employ a significant proportion of people in sparsely populated regions. Therefore, the number of accessible jobs can be considered to depict the agglomeration of economic activities rather than the rate of regional employment.

\section{Regional accessibility potential by car}

The dominance of a few cities in the south, particularly the capital region, forms the major pattern in regional accessibility potentials. The centre-periphery polarisation in Finland is particularly evident when the accessibility is measured with travel estimates based on speed limits (Figure 3). However, during the most intensive peaks, daily congestion may strongly affect accessibility in some of the urban centres, Helsinki in particular, where traffic is slower due to congestion (see:Salonen\&Toivonen 2013). The influence of Helsinki on potential accessibility is evident in Southern Finland and the grid cell analysis shows the significance of motorways between the capital and major cities in the south. For the rest of the country, the level of potential accessibility is low or extremely low, with the exception of the surroundings of the regional centres. Indeed, the population of urban regions in Finland have an almost $225 \%$ higher average potential accessibility by car than the national average, whereas the corresponding figure for rural areas in only approximately $20 \%$ of the national average. This highly polarised trend is not likely to change in the near future as the population in highly 
accessible urban areas is increasing due to migration from peripheries (Kotavaaraet al. 2012). Also, the present transport policy directs relatively limited funds to the development of transport links between the largest population centres, whereas funding for the maintenance of the rural road network is not adequate to compensate for wearing down of the road network.

\section{Access to regional centres by public transport}

Finland has a wide range of different types of population centres, from a few sprawling cities to numerous small rural villages surrounded by active agricultural areas and intermediate or deep peripheries located mainly in northern and eastern parts of the country, as well as in the coastal archipelago. The public transport network most efficientlyserves the urban centres, their immediate surroundings, and areas penetrated by long-haul transport. Fast railway links connect mainly the biggest cities as the number of stops at minor stations is limited. Thus, travel times to Finnish regional centres, as well as the service level of public transport, vary greatly (Figure 4).

In general, travel times to regional centresby public transport are longer than by car, except within the immediate proximity to fast railway connections. The public transport system is efficient in and between urban centres and in their immediate surroundings. The cities in southern Finland have a moderate reach of population within 60-minutes' travel time, but even in the south there are peripheries between cities in terms of accessibility by public transport. Because of fast railway connections, accessibility in the surroundings of Helsinki and Turku (in the south-west) is clearly better that in the case of other major cities. The railway corridors are clearly visible on the map portraying travel times. However, travel times of two hours or more are common in Centraland EasternFinland. The grid-based assessment shows in particular that there are a lot of small scale variations in public transport accessibility. In practice, accessibility by coach can range from very low to relatively good within a matter of a few kilometres, if there happen to be remarkable gaps in the network. The regions in Northernand North-Eastern Finland are particularly distant from regional centres. Therefore, a passenger car is the only reasonable transport mode in these areas, and when public transport is made available, it relies on subsidies and other special arrangements. Unless the requisite service level can be sustained on a market basis, municipalities support public transports within their own administrative area and inter-municipal connections are supported by government subsidy instruments. Nevertheless, in the deepest peripheries the bus services may operate less frequently than on a daily basis, and due to low demand for bus services in some cases public transport is operated solely with taxis (see: Ylipiessa\&Hyvönen 2012).

\section{Access to health care facilities by car}

Hospitals are well accessible by car around almost all major population centres in Finland, as the present hospital network is fairly dense in relation to the population structure (Figure 5). It is obvious that the health care network has been designed so that it provides reasonable access to health care for most of the people in every part of the country. In the urban areas and within their main transport corridors, accessibility of health care is clearly very good. In addition, areas adjacent to the regional centres have at least a moderate level of accessibility. National average accessibility to health care by car is about 20 minutes. Deep contrast to this service level is evident in sparsely populated Easternand Northernparts of Finland, as the absence of medical services results in a need for very long travel. Travel time is close to or longer than 60 minutes only in eastern and northern parts of the country. However, in the most peripheral and sparsely populated areas travel times to the closest health care facility can be over five hours by car, and obviously even more with public transport. 


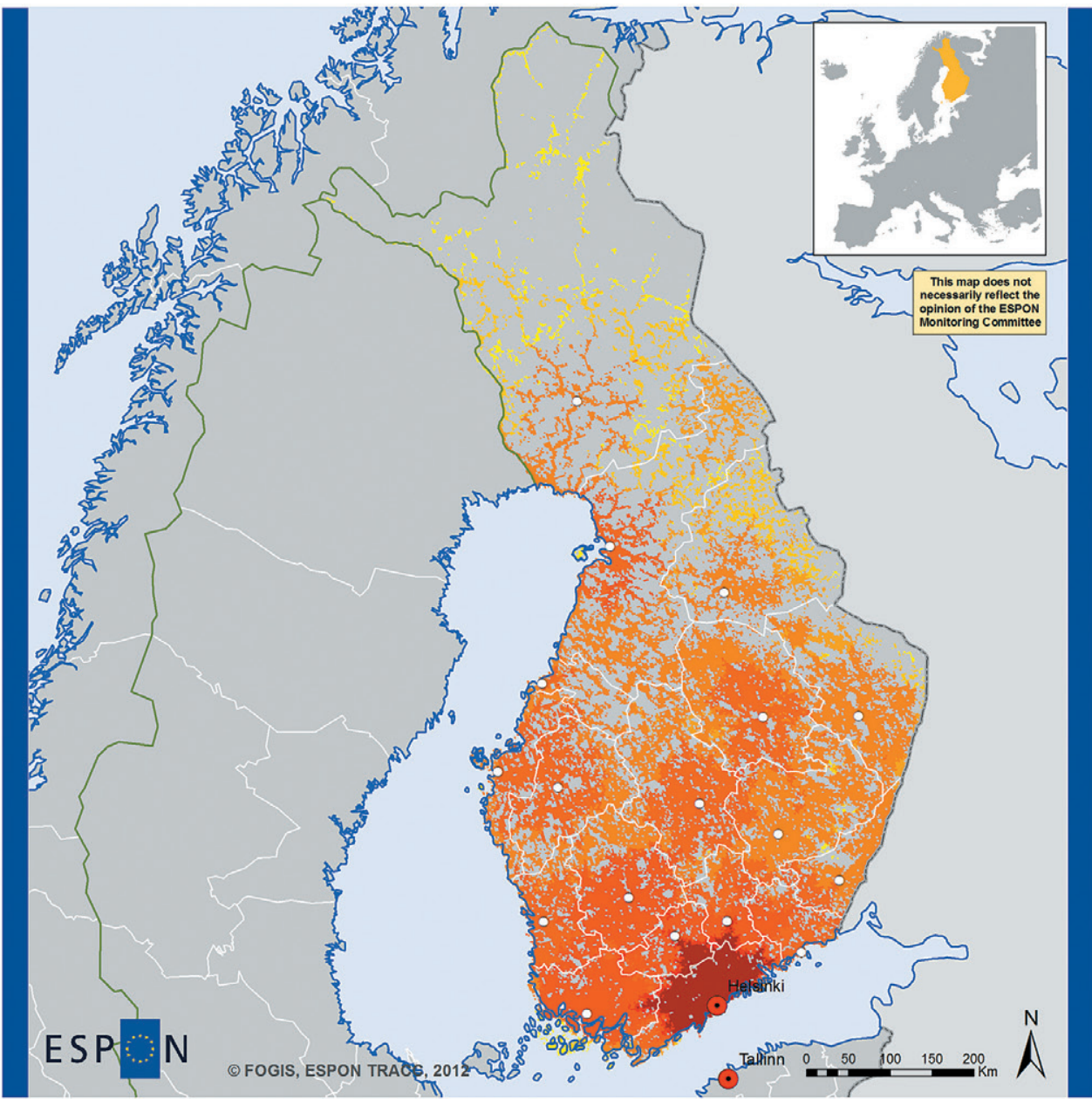

EUROPEAN UNION

art-financed by the European Regional Development Fund INVESTING IN YOUR FUTURE

Data source: Finnish Transport Agency, 2012, Statistics Finland, 2011, 2010, 2008 Origin of data: ESPON Databank Project, 2010/2011 (c) Euro Geographics Association for administrative boundaries

\section{Finland Case Study Jobs accessible by car within $\mathbf{6 0}$ minutes (raster level)}

$0-2,500$

$2,501-5,000$

$5,001-10,000$

$10,001-50,000$

$50,001-100,000$

$100,001-250,000$

$250,001-500,000$

$500,001<\ldots$

Figure 2. Jobs accessible within 60 minutes by car. 


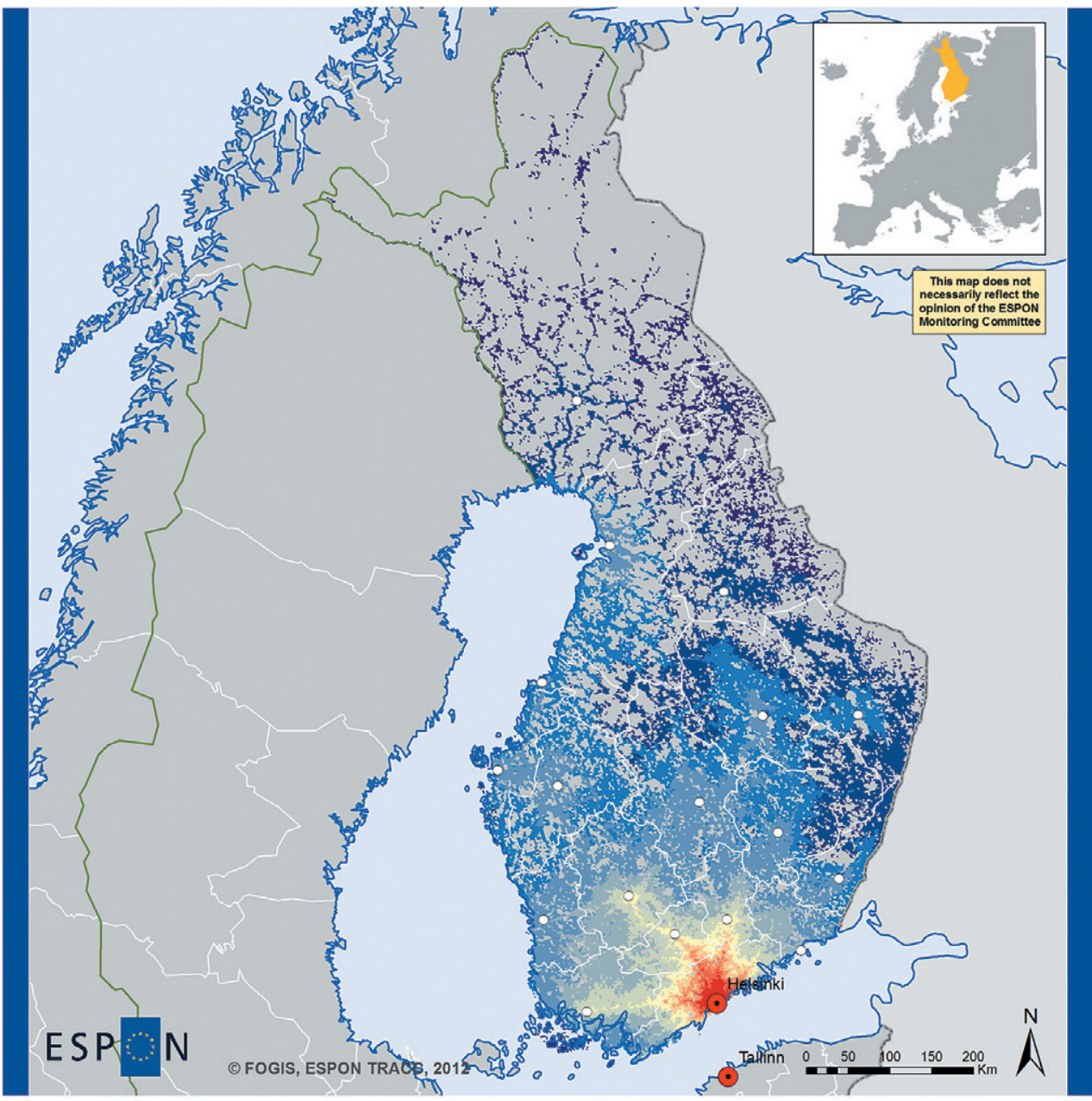

EUROPEAN UNION INVESTING IN YOUR FUTURE

Data source: Finnish Transport Agency, 2012, Statistics Finland, 2011, 2010 Origin of data: ESPON Databank Project, 2010/2011

\section{Finland Case Study}

Potential accessibility to population by car (raster level)

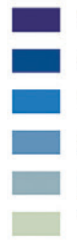

$0-5.0$

$5.1-15.0$

$100.1-125.0$

100 (population weighted average, car) $=302283.4$

$125.1-150.0$

Maximu

$15.1-25.0$

$150.1-175.0$

$25.1-50.0$

$175.1-200.0$

$50.1-75.0$

$200.1<\ldots$

75.1 - 100.0

Figure 3. Potential accessibility to population by car. 


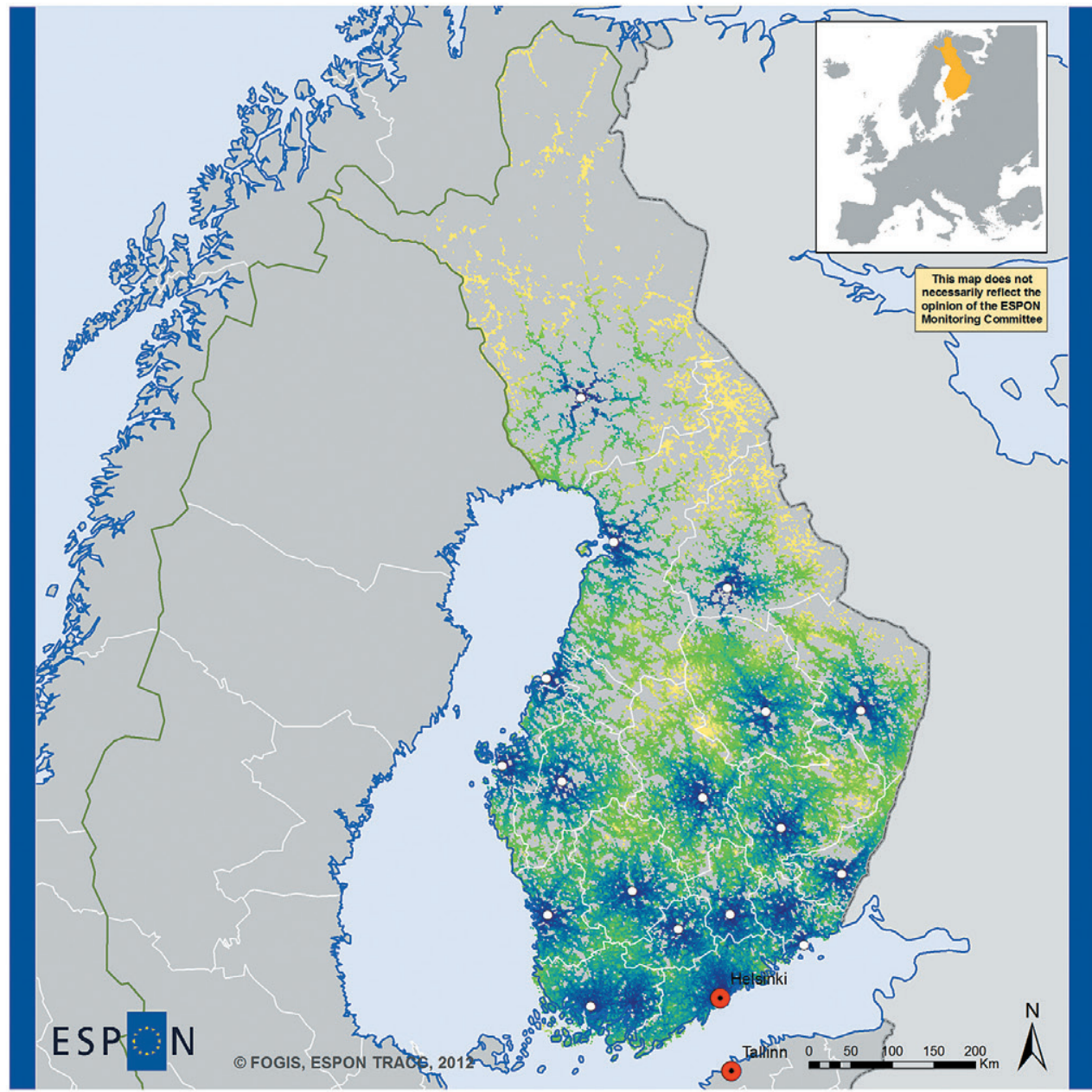

EUROPEAN UNION Part-financed by the European Regional Development Fund
INVESTING IN YOUR FUTURE

Data source: Finnish Transport Agency, 2012, Statistics Finland, 2011, 2010 , Oy Matkahuolto $A b, 2012$ Origin of data: ESPON Databank Project, 2010/2011

\section{Finland Case Study}

Travel time by public transport to nearest regional centre (raster level)

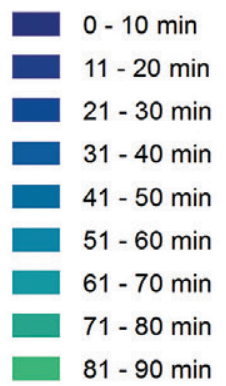
$91-100 \mathrm{~min}$
$101-110 \mathrm{~min}$
$111-120 \mathrm{~min}$
$121-130 \mathrm{~min}$
$131-140 \mathrm{~min}$
$141-150 \mathrm{~min}$
$151-160 \mathrm{~min}$
$161-170 \min$
$171<\ldots \min$

Figure 4. Travel time to nearest regional centre by public transport. 


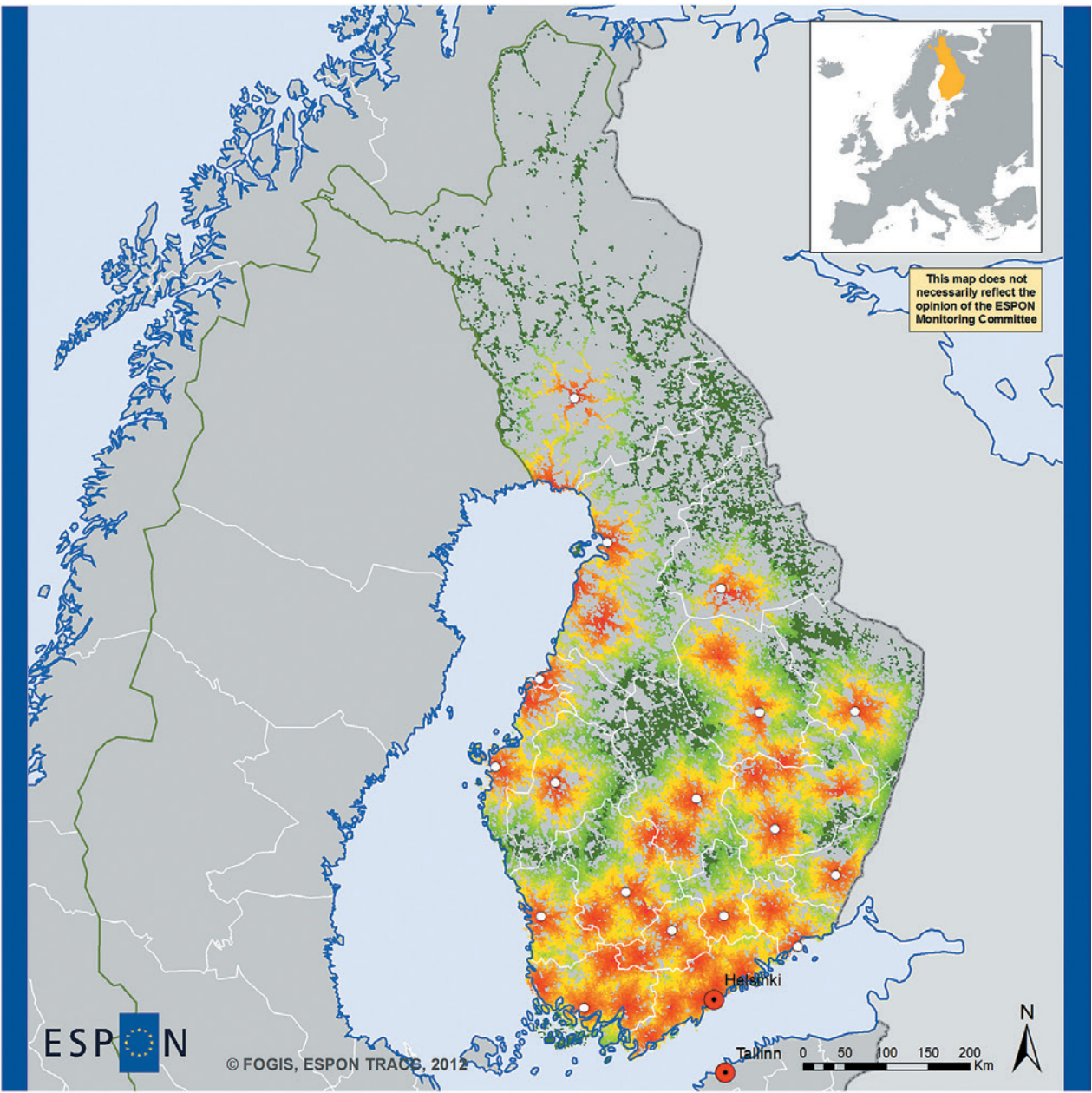

$\vdots \vdots \quad \begin{aligned} & \text { EUROPEAN UNION } \\ & \text { Part-financed by the European Regional Development Fund }\end{aligned}$ INVESTING IN YOUR FUTURE

Finland Case Study Car travel time to nearest hospital (raster level)

\begin{tabular}{|l|l}
\hline $0-5 \mathrm{~min}$ & $36-40 \mathrm{~min}$ \\
$6-10 \mathrm{~min}$ & $41-45 \mathrm{~min}$ \\
$11-15 \mathrm{~min}$ & $46-50 \mathrm{~min}$ \\
$16-20 \mathrm{~min}$ & $51-55 \mathrm{~min}$ \\
$21-25 \mathrm{~min}$ & $56-60 \mathrm{~min}$ \\
$26-30 \mathrm{~min}$ & $61-65 \mathrm{~min}$ \\
$31-35 \mathrm{~min}$ & $66<\ldots \mathrm{min}$
\end{tabular}

Figure 5. Travel time to nearest hospital by car. 


\section{Impact of future TEN-T road network developments}

The TEN-T funded projects in Finland include investments in roads, railways, harbours and traffic management. For this study, all Finnish TEN-T-funded projects under construction or in the planning phase were surveyed (in addition, several TEN-T projects were completed before the study started and many transport investments are made nationally). The planned transport links were manually digitised and included into the network datasets. Thanks toavailability of very recent data, the effect of actual future investments could be considered in this case study. The key finding was that TEN-T policies are actively exploited in Finland, but the great majority of projects are focused on improving nodal transport infrastructure.

Only a few future or ongoing TEN-T projects are direct investments into the development or construction of road or railway links. The particular TEN-T projects included in the study of car travel accessibility are road upgrades for extending the southern motorway network towards the eastern border and to the north-east (Figure 6) (European Commission 2011, Finnish Transport Agency 2012, TEN-T Executive Agency 2012). The only noticeable relative increase in potential accessibility by car is achieved with the eastern motorway upgrade, and the effect is visible mainly ona sub-regional scale (Biosca et al., 2013) (Figure 6). For municipal level analysis, accessibility scores were calculated for raster cells and then transferred to the regional level by means of population-weighted averaging.

The reach and quality of the transport networks in Finland are at a relatively good level, especially when compared to demand. Network investments may be considered to develop and improve infrastructure rather than to establish it. Therefore, absolute improvements yielded by the investments may be very efficient in terms of transport volumes, but relatively low when measured in travel times. The effect of transport investments can be considered to affect heavy freight transports and traffic safetyto a greater extent, and it may also help reduce congestion in certain places. 


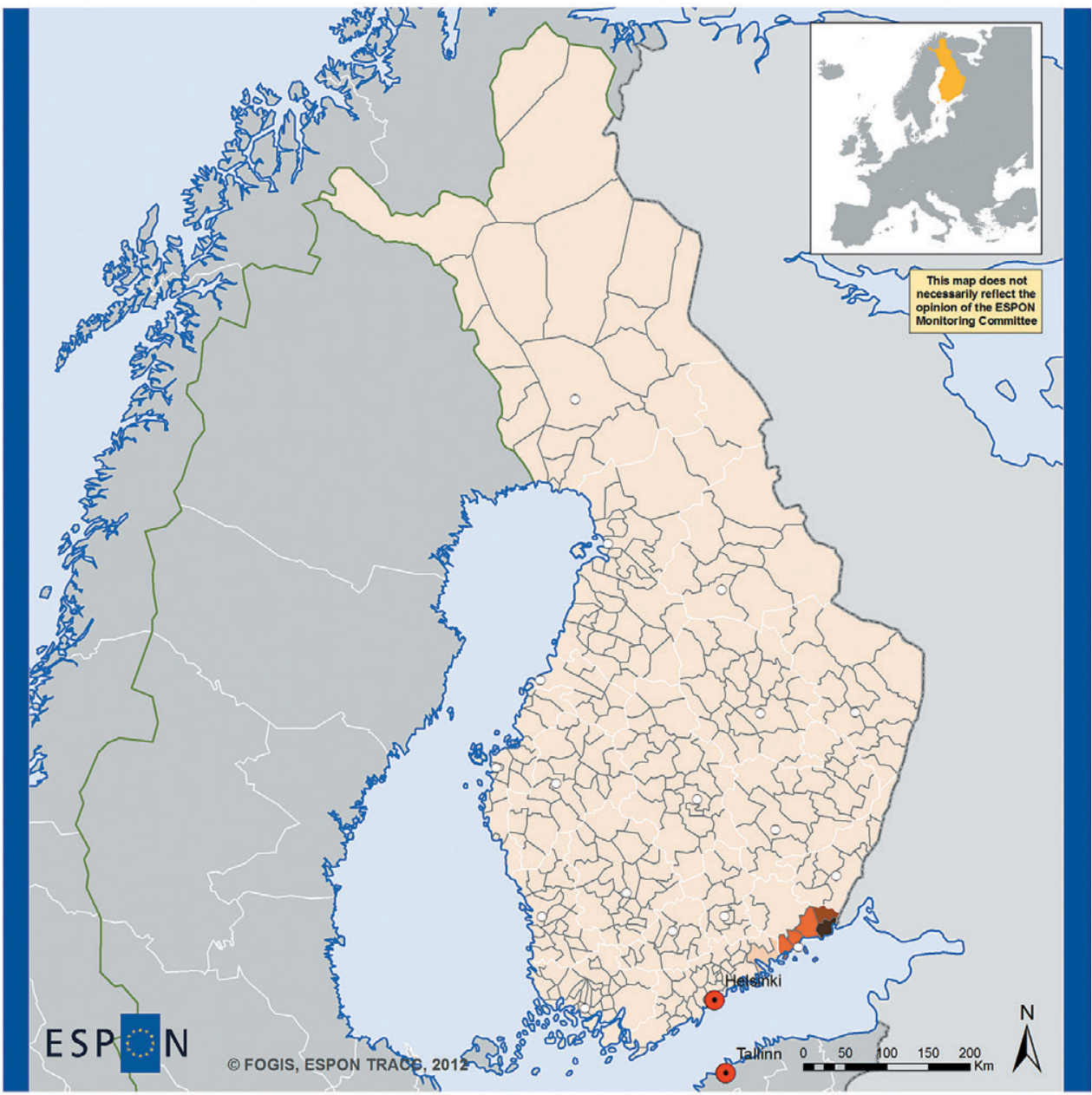

$\because \quad$ EUROPEAN UNION

Part-financed by the European Regional Development Fund INVESTING IN YOUR FUTURE

Data source: Finnish Transport Agency, 2012, Statistics Finland, 2011, 2010 Origin of data: ESPON Databank Project, 2010/2011 (C) EuroGeographics Association for administrative boundaries

\section{Finland Case Study}

Relative increase of potential accessibility to population by car with TEN-T projects (municipality averages)

$0-5.0$

$5.1-10.0$

$10.1-15.0$

$15.1-20.0$

$20.1-25.0$

$25.1<\ldots$

Figure 6. Relative increase of potential accessibility to population by car with TEN-T projects. 


\section{Conclusions}

Finland as a whole is one of the most sparsely populated countries in Europe. In the spatial divisions of the population and jobs, the presence of both urban densities and extremely sparsely populated areas that have long distances to major population centres is evident in the analyses of accessibility. Polarisation is intense in the centre-periphery axis when compared to European standards, and the division is deepening due to the location choices of companies and overall urbanisation process.

The availability of services is relatively good, even in peripheral areas, but naturally the number of choices decreases with decreasing demand. This is evident in the case of health care accessibility. There are hospitals in every major city and town, and accessibilityof basic health care corresponds to the spatial distribution of the population. Only in sparsely populated peripheries accessibility of services can be considered poor. Indeed, accessibility of major regional centres and particularly accessibility of jobs displayed major differences between cores and peripheries, but accessibility of hospitals is generally more equal. While the average travel time to the nearest hospital by car is over 10 minutes in urban areas of Finland, approximately 30 minute average travel time in rural areas can be considered normal. In practice, low accessibility of hospitals in northern and eastern parts of the country cannot be improved with transport network investments, and the reduction of the service network is a more likely development than extending it (see: Huotari et al. 2012). However, relatively equal accessibility of hospitals is evident as $50 \%$ of the rural population can reach the nearest hospital in about 15 minutes by car, which is not significantly higher than the average values of urban centres and intermediate areas. It should be noted, though, that especially in rural areas travel times by public transport are much longer than by car, and in some cases public transport may not be available at all. Furthermore, in comparison with specialised health care provided by regional hospitals, accessibility of emergency units is much better due to a more dense service network and the use of rescue helicopters in critical cases (see:Huotari et al. 2013).

The car is undisputedly the dominant travel mode in Finland. The regional structure favours travelling by car in areas outside urban centres, and in peripheral areas the availability of public transport is limited. For all accessibility indicators, accessibility by public transport is significantly lower than by car in all parts of the country, with the possible exception of the capital city and its surrounding areas and the core areas of other major cities. Outside the immediate surroundings of centres, accessibility by public transport decreases rapidly and in the deepest peripheries public transport services are totally absent. Because of the geography of Finland, distances are generally long, transport flows are thin, and there is not sufficient population in many areas to ensure sufficient demand for public transport.

The capital region and its surroundings clearly stand out as areas with good accessibility compared to other parts of the country. However, congestion problems are common and often the accessibility of the area is much lower than the optimal situation implies. The other major population centres, especially regional capitals, constitute the second best category of accessibility, while large peripheral regions are generally characterised by low accessibility. However, rural areas exhibit different levels of accessibility in different parts of the country. In the eastern and northern regions in particular, accessibility of services for the rural population is extremely poor, while in some predominantly rural regions the presence of strong regional centres may be associated with improved indicators of accessibility. In the Finnish case study, Lapland and Eastern Finland emerge as remote peripheries with accessibility limited by long distances and sparse service network. 
Transport corridors and networking between urban regions and centres within their zones of influence have been the key element oftheFinnish transport policy (Ministry of the Environment, 2006). In order to secure the needs of foreign trade, functional transport connections with all parts of the world must exist. Indeed, in economic terms the most important elements of the Finnish transport system are connections with foreign countries (harbours and aviation in particular), capacity and the level of service of trunk roads and railways, the internal transport system of Helsinki, and the connections between the most important regional centres. The fundamental requirement of a functioning logistics chain is that the services of the road and railway infrastructure, as well as harbours, are available. In the case of Finland, it has to be noted that the availability of services is also critical in winter. This is something that cannot be taken for granted, especially in the northern latitudes. In this regard, the use of ice-strengthened ships and icebreakers in maritime transport during the winter season is a special need of the Finnish transportation system, also affecting international accessibility.

In early 2012, the Finnish government published an extensive report on national transportation policy (Liikenneja-viestintäministeriö, 2012). The Finnish transport policy and the transport system are tightly connected with the other functions of society, including the requirements of the industry, economy and employment, as well as regional development, since good accessibility is the key factor in economic development and prosperity of the regions. In contrast, improving the accessibility of remote rural areas will not be the focus of the Finnish transport policy. Effectively, this signifies that these areas will remain in a disadvantaged position in terms of accessibility in the future, as the development measures will mostly be directed at regions which have the most favourable conditions with regard to economic activity andthepopulation.

The majority of the findings of this study are based on grid cell maps, free of administrative divisions. Several particular areas and spatial patterns can be seen only on the grid cell basis. The LAU2 division, i.e. the municipal structure of Finland, is sparse in some areas and municipal consolidations have been common. There are significant political efforts to reduce the number of municipalities even further. Therefore, it is important to acknowledge that the spatial analysis based on the municipal classification suffers from a loss of accuracy, and comparability between different years is poor. This underpins the argument that LAU2 classifications need supplemental regional classification systems, which could be based on grid cells. In Finland, this type of regional typology has recently been introduced to official use (Finnish Environment Institute 2012).

The components of accessibility are, in general, the accessed place or object and travel to reach it. Population distribution changes slowly and transport networks maybe even more slowly, particularly in Finland, whilst coverage with road and railway networks has reached a sort of maturity. Thus, the service supply, location choices of companies and population change will evidently have a greater impact on accessibility development in Finland than any foreseen transport investments.

\section{Acknowledgement}

We thank Oy Matkahuolto Ab for sharing their data on bus stop locations for this study. We also wish to thank Janne Pöllänen for his valuable work as research assistant in constructing the public transport datasets. The work done by Juhani Päivärinta for digitising the basic health care facility locations is also acknowledged. 


\section{References}

Biosca O., Spiekermann K., Stępniak M., 2013. Transport accessibility at regional scale, EUROPA XXI, vol. 24, pp. 5-17.

European Commission, 2011. Proposal for a Regulation of the European Parliament and of the Council on Union Guidelines for the Development of the Trans-European Transport Network.COM(2011) 650/2. http://eur-lex.europa.eu/LexUriServ/LexUriServ.do?uri=CELEX:52011PC0650R(01):EN: NOT [25 September 2013].

Finnish Environment Institute, 2012. Aluetypologia - kaupungin ja maaseudun paikkatietoperusteinen aluerajaus, alueluokituksen kommentointi.

Finnish Transport Agency, 2012. Hankeet. http://portal.liikennevirasto.fi/sivu/www/f/hankkeet [25 September 2013].

Huotari T., Antikainen H., Pukkinen M., Rusanen J., 2012. Synnytyspäivystyksen ja erikoissairaanhoidon palveluiden saavutettavuus. Sosiaali-ja terveysministeriön raportteja ja muistiota, 2012:29, Ministry of Social Affairs and Health.

Huotari T., Antikainen H., Rusanen J., 2013. Perusterveydenhuollon ympärivuorokautisten päivystyspisteiden saavutettavuus. Sosiaali-ja terveysministeriön raportteja ja muistioita, 2013:27, Ministry of Social Affairs and Health.

Kotavaara O., Antikainen H., Rusanen J., 2011a. Population change and accessibility by road and rail networks: GIS and statistical approach to Finland 1970-2007. Journal of Transport Geography 19, pp. 926-935.

Kotavaara O., Antikainen H., Rusanen J., 2011b. Urbanization and transportation in Finland, 18801970: A GIS analysis. Journal of Interdisciplinary History 42, pp. 89-109.

Kotavaara O., Antikainen H., Marmion M., Rusanen J., 2012. Scale in the effect of accessibility on population change: GIS and a statistical approach to road, air and rail accessibility in Finland, 1990-2008. The Geographical Journal 178, pp. 366-382.

Liikenne- javiestintäministeriö, 2012. Kilpailukykyä ja hyvinvointia vastuullisella liikenteellä. Valtioneuvoston liikennepoliittinen selonteko eduskunnalle 2012. http://www.hare.vn.fi/upload/ Julkaisut/17748/670671812912207.PDF [25 September 2013].

Ministry of the environment, 2006. Competitiveness, welfare and eco-efficiency.Perspectives for spatial structure and land use in Finland. The Finnish Environment.

Rusanen J., Muilu T., Colpaert A., Naukkarinen, A., 2003. Georeferenced data as a tool for monitoring the concentration of population in Finland in 1970-1980. Fennia 181, pp. 129-144.

Salonen M., Toivonen T., 2013. Modelling travel time in urban networks: comparable measures for private car and public transport. Journal of Transport Geography 31, pp. 143-153.

Statistics Finland, 2011. Grid Database. http://www.stat.fi/tup/ruututietokanta/index_en.html [25 September 2013].

Statistics Finland, 2012a. Työssäkäynti http://pxweb2.stat.fi/database/StatFin/vrm/tyokay/tyokay_ fi.asp [25 September 2013].

Statistics Finland, 2012b. Labour Market, Population by activity, Unemployment. http://www.stat. fi/tup/suoluk/suoluk_tyoelama_en.html [25 September 2013].

Statistics Finland, 2012c. Maakuntienpinta-ala, väestö ja bruttokansantuote (NUTS 3). http://www. stat.fi/tup/suoluk/suoluk_vaesto.html [25 September 2013]. 
TEN-T Executive Agency, 2012. TEN-T Projects by Country, Finland. http://tentea.ec.europa. eu/en/ten-t_projects/ten-t_projects_by_country/finland.htm [25 September 2013].

Ylipiessa K., Hyvönen A.-S., 2012. Lapin joukkoliikenteen palvelutaso 2012-2016. Lapin elinkeino-, liikenne- jaympäristökeskus, Centre for Economic Development, Transport and the Environment, http://www.doria.fi/bitstream/handle/10024/84789/Raportteja_47_2012.pdf?sequence=1 [25 September 2013]. 


\section{ALL VOLUMES OF EUROPA XXI}

23 (2013) : Services of General Interest in European Union

22 (2012) : Territorial development and cohesion in a multi-scalar perspective

21 (2010) : Environmental and infrastructural networks

20 (2010) : European Union: external and internal borders, interactions and networks

19 (2009) : European urban system: metropolization and networking

18 (2008) : Territorial dilemmas of socio-economic development in Europe

17 (2008) : New functions of rural and industrial space in Central and Eastern Europe

16 (2007) : Regional development in Central Europe - cohesion or competitiveness

15 (2006) : Regional periphery in Central and Eastern Europe

14 (2006) : Core and peripheral regions in Central and Eastern Europe

13 (2005) : New spatial relations in new Europe

12 (2005) : Central and Eastern Europe: changing spatial patterns of human activity

11 (2004) : Przestrzeń Europy. Przestrzeń Unii Europejskiej

10 (2003) : Society and environment. Towns and settlement in Europe

9 (2003) : Polska i Europa: kształtowanie przestrzeni wolności

8 (2003) : European space in the face of enlargement: the West to East European Trajectory project

7 (2002) : Slovakia and Poland: urban, social and demographic questions, relations between neighbours

6 (2001) : Integracja europejska - dylematy spójności i konwergencji regionalnej

5 (2000) : Przestrzeń ekologiczna Polski. Dekolektywizacja rolnictwa

i sytuacja zdrowotna w Europie Środkowej,

Wschodniej i Południowo-Wschodniej

4 (2000) : Powiązania handlowe Polski z Europą. Z debaty

o przyszłym kształcie zjednoczonej Europy

3 (1999) : Obszary szczególnej troski i nowych możliwości rozwoju na przykładzie Polski i Ukrainy

2 (1998) : Przestrzeń Europy Środkowej - przykłady transformacji

1 (1998) : Sieć komunikacyjna Polski w europejskich procesach integracyjnych 


\section{Transport accessibility at regional scale in Europe}

- Oriol Biosca, Klaus Spiekermann, Marcin Stępniak Transport Accessibility at Regional Scale

- Rafael Rodrigo, Nati Franco, Oriol Biosca, Andreu Ulied Accessibility patterns: West Mediterranean Case Study

- Davide Fiorello, Dorota Bielańska Accessibility patterns: Northern Italy Case Study

- Klaus Spiekermann Accessibility patterns: Bavaria Case Study

- Miroslav Marada, Viktor Květoň, Tomáš Mattern, Přemysl Štych, Tomáš Hudeček Accessibility patterns: Czech Republic Case Study - Marcin Stępniak, Piotr Rosik, Tomasz Komornicki Accessibility patterns: Poland Case Study

- Carsten Schürmann Accessibility patterns: Baltic States Case Study

- Ossi Kotavaara, Harri Antikainen, Jarmo Rusanen Accessibility patterns: Finland Case Study

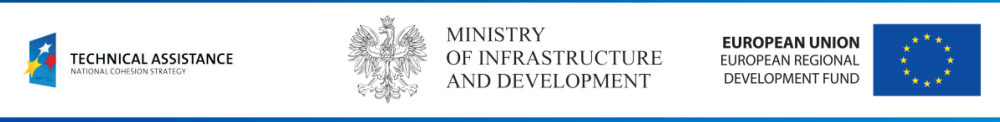

